\title{
Efektifitas Pemberian Diet Beras Merah Dalam Menurunkan Kadar Gula Darah Pada Penderita Diabetes Mellitus Di Puskesmas Pademawu Pamekasan
}

\author{
Kuszairi $^{1}$ \\ ${ }^{1}$ Akper Pemkab Pamekasan Madura \\ Email: putramandalatrans@gmail.com
}

\begin{abstract}
ABSTRAK
Diabetes mellitus (DM) adalah suatu penyakit dimana kadar glukosa darah tinggi karena tubuh tidak dapat melepaskan atau menggunakan insulinsecara cukup. Pengobatan diabetes meliputi pengendalian berat badan, olahraga dan diet. Salah satu cara diet adalah menggunakan beras merah. Tujuan penelitian ini untuk mengetahui keefektifitasan pemberian diet beras merah dalam menurunkan kadar gula darah pada penderita DM. Desain penelitian ini menggunakan desain penelitian Quasy-Experiment dengan metode Simple Random Sampling.Sample yang digunakan sebanyak 16 responden dari jumlah populasi 76 pasien DM yang melakukan rawat jalan di Puskesmas Palengaan pada bulan Juni 2008. Pengumpulan data dilakukan dengan mengobservasi kadar gula darah sebelum dan sesudah dilakukan intervensi diet beras merah dengan menggunakan alat GlucoDr. Setelah ditabulasi, data yang ada dianalisis dengan menggunakan Uji T Sampel Berpasangan dengan tingkat kemaknaan 0,05 . Hasil pengujian statistik diperoleh bahwa $\mathrm{H}_{0}$ ditolak dan $\mathrm{H}_{1}$ diterima, artinya diet beras merah efektif terhadap penurunan kadar gula darah pasien DM dengan nilai t hitung 7,202 dengan tingkat signifikan 0,000. Mengingat dari hasil penelitian ini membuktikan bahwa diet beras merah dapat menurunkan kadar gula darah penderita DM sehingga perlu adanya kesadaran dari penderita DM untuk melaksanakan diet beras merah agar dapat mengurangi resiko terjadinya komplikasi dari DM.
\end{abstract}

Kata kunci: Diet, Beras merah, Kadar gula, Diabetes Mellitus.

\begin{abstract}
Diabetes mellitus (DM) is a disease in which blood glucose levels are high because the body can not release or use insulins sufficiently. Treatment of diabetes includes weight control, exercise and diet. One way of diet is to use brown rice. The purpose of this study to determine the effectiveness of red rice diet in lowering blood sugar levels in patients with DM. The design of this research used Quasy-Experiment research design with Simple Random Sampling method. The sample used was 16 respondents from population of 76 DM patients who performed outpatient at Puskesmas Palengaan in June 2008. Data collection was done by observing the blood sugar level before and after intervention of red rice diet using GlucoDr tool. After being tabulated, the existing data were analyzed by using Paired Sample $\mathrm{T}$ Test with a significance level of 0.05 . The results of statistical tests obtained that $\mathrm{H} 0$ rejected and $\mathrm{H} 1$ accepted, meaning red rice diet is effective against the decrease in blood sugar levels DM patients with a value of $t$ count of 7.202 with a significant level of 0.000 . Given the results of this study proves that the red rice diet can reduce blood sugar levels of DM patients so the need for awareness of DM patients to implement a red rice diet in order to reduce the risk of complications from DM.
\end{abstract}

Keywords: Diet, Brown Rice, Sugar Level, Diabetes Mellitus 


\section{PENDAHULUAN}

Penyakit DM yang lebih dikenal di Indonesia dengan sebutan penyakit kencing manis merupakan salah satu penyakit yang prevalensinya kian meningkat. Berdasarkan data organisasi dunia (WHO) dalam [1], di Indonesia pada tahun 2003 tercatat 13 juta penderita diabetes mellitus dan diperkirakan akan meningkat lebih dari 20 juta penderita pada tahun 2030. Hal ini dibuktikan pada pencacatan selanjutnya dalam [2], WHO mencatat pada tahun 2006 terdapat sekitar 14 juta orang di Indonesia yang menderita penyakit Diabetes Mellitus dan dari jumlah itu baru 50\% penderita yang sadar mengidap Diabetes Mellitus dan hanya $30 \%$ dari penderita yang sadar tersebut melakukan pengobatan secara teratur. Saat ini Indonesia menempati urutan keempat terbesar dalam jumlah penderita Diabetes Mellitus (diabetasi) di dunia. Sedangkan di Pamekasan, berdasarkan data Dinas Kesehatan Pamekasan tahun 2007 penderita DM mencapai 888 Orang dan meningkat menjadi 1.353 Orang pada tahun 2008. Peneliti telah melakukan pendataan di Puskesmas Pademawu dan tercatat 10 orang di akhir tahun 2007 dan meningkat menjadi 76 orang di akhir tahun 2008.

Menurut Sidartawan, tendensi kenaikan kekerapan Diabetes Mellitus secara global terutama dipacu oleh peningkatan kesejahteraan suatu populasi sehingga sangat dimungkinkan dalam kurun waktu satu-dua dekade silam kekerapan Diabetes Mellitus di Indonesia telah menjadi signifikan. Hal ini di pacu oleh faktor-faktor seperti demografi, gaya hidup, serta berkurangnya penyakit infeksi kurang gizi [3]. Diabetes Mellitus timbul karena faktor keturunan dan perilaku. Faktor keturunan merupakn faktor yang tidak dapat diubah, tatapi faktor lingkungan yang berkaitan dengan gaya hidup seperti kurang berolahraga dan asupan nutrisi yang berlebihan serta kegemukan merupakan faktor yang dapat diperbaiki. Diabetasi harus mengubah gaya hidup tersebut agar peningkatan kadar gula darah secara terus menerus dapat dicegah. Kadar gula yang tinggi secara terus menerus berakibat rusaknya pembuluh darah, syaraf dan struktur internal lainnya [4].

Menurut [5], Diabetes Mellitus juga bisa menimbulkan berbagai komplikasi kronik pada mata, ginjal, syaraf dan pembuluh darah. Oleh karena itu untuk mencegah terjadinya komplikasi tersebut Mansjoer [6], mengatakan perlu adanya pengaturan pola makan dengan gizi seimbang sebagai upaya pencegahan dengan melakukan diet Diabetes Mellitus yang bertujuan menyesuaikan makanan dengan kesanggupan tubuh untuk menggunakannya agar pasien dapat mengerjakan pekerjaan sehari-hari seperti biasa. Syarat diet ini adalah jumlah kalori ditentukan menurut umur, jenis kelamin, berat badan dan tinggi badan, aktivitas, suhu 
tubuh dan kelainan metabolik. Dalam [7], diet yang dinjurkan bagi diabetasi adalah makanan dengan komposisi yang seimbang dalam hal karbohidrat, protein dan lemak sesuai dengan kecukupan gizi.Diabetasi sebaiknya mengkonsumsi makanan yang bergizi rendah karbohidrat dan lemak namun tinggi protein, vitamin dan mineral [8].

Dalam [8], beras merah merupakan sumber karbohidrat yang tinggi protein, vitamin dan mineral serta rendah karbohidrat. Di bandingkan beras putih, kandungan karbohidrat beras merah lebih rendah (78,9 gram : 75,7 gram) tapi nilai energi yang dihasilkan beras merah justru lebih besar (349 kal : $353 \mathrm{kal})$. Selain lebih kaya protein $(6,8$, gram : 82 gram), beras merah juga mengandung vitamin $\mathrm{B} 1$ yang lebih tinggi $(0,12 \mathrm{mg}: 0,31 \mathrm{mg})$. Sebagai sumber karbohidrat kompleks, beras merah tidak menaikan kadar gula darah dengan cepat sehingga baik diasup oleh penderita Diabetes Mellitus [9]. Beras merah juga mengandung mineral, asam lemak dan kaya akan serat [10]. Serat dapat menurunkan gula darah karena serat dapat mengurangi penyerapan glukosa oleh usus [11].

\section{TUJUAN}

Mengidentifikasi efektifitas diet beras merah dalam menurunkan kadar gula darah Abnormalitas Asam Basa pada penderita Diabetes Mellitus di Puskesmas Pademawu.Mengidentifikasi pemberian beras merah dalam menurunkan kadar gula darah Abnormalitas Asam Basa pada penderita Diabetes Mellitus di Puskesmas Pademawu.Mengetahui pengaruh pemberian diet beras merah terhadap penurunan kadar gula darah Abnormalitas Asam Basa pada penderita Diabetes Mellitus di Puskesmas Pademawu.

\section{TINJAUAN PUSTAKA}

\section{Diabetes Mellitus}

Diabetes mellitus oleh WHO didefinisikan sebagai suatu penyakit atau gangguan metabolisme kronis dengan multi etiologi yang ditandai dengantingginya kadar gula darah disertai dengan gangguan metabolisme karbohidrat,lipid dan protein sebagai akibat insufisiensi fungsi insulin. Insufisiensi fungsi insulin dapat disebabkan oleh gangguan atau defisiensi produksi insulin oleh sel-sel $\beta$ Langerhans kelenjar pankreas, atau disebabkan oleh kurangresponsifnya sel-sel tubuh terhadap insulin [12].

\section{Patofisiologi}


Diabetes Mellitus merupakan suatu kelainan yang heterogenik dengan karakter utama hiperglikemia kronis. Meskipun pola pewarisannya belum jelas, faktor genetik dikatakan memiliki peran yang kuat dalam munculnya Diabetes Mellitus ini. Faktor genetik ini akan berinteraksi dengan faktor lingkungan seperti gaya hidup, diet, rendahnya aktivitas fisik, obesitas dan tingginya kadar asam lemak bebas. Pada Diabetes Mellitus terjadi defek sekresi insulin, resistensi insulin di perifer dan gangguan regulasi produksi glukosa oleh hepar. Sebagian besar patologi diabetes mellitus dapat dikaitkan dengan satu dari tiga efek utama kekurangan insulin sebagai berikut : (1) Pengurangan penggunaan glukosa oleh sel-sel tubuh, dengan akibat peningkatan konsentrasi glukosa darah setinggi 300 sampai 1200 $\mathrm{mg} / \mathrm{hari} / 100 \mathrm{ml}$. (2) Peningkatan mobilisasi lemak dari daerah-daerah penyimpanan lemak, menyebabkan kelainan metabolisme lemak maupun pengendapan lipid pada dinding vaskuler yang mengakibatkan arterosklerosis. (3) Pengurangan protein dalam jaringan tubuh. Akan tetapi selain itu terjadi beberapa masalah patofisiologi pada diabetes mellitus yang tidak mudah tampak yaitu kehilangan ke dalam urine klien diabetes mellitus. Bila jumlah glukosa yang masuk tubulus ginjal dan filtrasi glomerulus meningkat kira-kira diatas 225 mg.menit glukosa dalam jumlah bermakna mulai dibuang ke dalam urine. Jika jumlah filtrasi glomerulus yang terbentuk tiap menit tetap, maka luapan glukosa terjadi bila kadar glukosa meningkat melebihi $180 \mathrm{mg} \%$. Asidosis pada diabetes adalah manfestasi pergeseran dari metabolisme karbohidrat yaitu tubuh menggantungkan hampir semua energinya pada lemak, kadar asam aseto - asetat dan asam Bihidroksibutirat dalam cairan tubuh [13]

\section{Gejala Klinis}

Diabetes Mellitus sering kali muncul tanpa gejala, gejala awalnya berhubungan dengan efek langsung dari kadar gula yang tinggi berupa polifagia, poliuria, polidipsia, lemas, dan berat badan turun. Gejala lain yang mungkin dikeluhkan pasien adalah kesemutan, gatal, mata kabur, dan impotensi pada pria, serta pruritus vulva pada wanita [14].

Pasien dengan diabetes tipe 1 sering memperlihatkan awitan gejala yang eksplosif dengan polidipsia, poliuria, turunnya berat badan, polifagia, lemah, somnolen yang terjadi selama beberapa hari atau beberapa minggu. Pasien dapat menjadi sakit berat dan timbul ketoasidosis, serta dapat meninggal kalau tidak mendapatkan pengobatan segera. Terapi insulin biasanya diperlukan untuk mengontrol metabolisme dan umumnya penderita peka terhadap insulin. Sebaliknya, pasien dengan diabetes tipe 2 mungkin sama sekali tidak memperlihatkan gejala apapun, dan diagnosis hanya dibuat berdasarkan pemeriksaan darah di laboratorium dan melakukan tes toleransi glukosa. Pada hiperglikemia yang lebih berat, 
pasien tersebut mungkin menderita polidipsia, poliuria, lemah dan somnolen. Biasanya mereka tidak mengalami ketoasidosis karena pasien ini tidak defisiensi insulin secara absolut namun hanya relatif. Sejumlah insulin tetap disekresi dan masih cukup untuk menghambat ketoasidosis. Kalau hiperglikemia berat dan pasien tidak berespons terhadap terapi diet, atau terhadap obat-obat hipoglikemik oral, mungkin diperlukan terapi insulin untuk menormalkan kadar glukosanya. Pasien ini biasanya memperlihatkan kehilangan sensitifitas perifer terhadap insulin. Kadar insulin pada pasien sendiri mungkin berkurang, normal atau malahan tinggi, tetapi tetap tidak memadai untuk mempertahankan kadar glukosa darah normal. Penderita juga resisten terhadap insulin eksogen [15].

\section{Diagnosis}

Keluhan dan gejala yang khas ditambah hasil pemeriksaan glukosa darah sewaktu $>200$ $\mathrm{mg} / \mathrm{dl}$ atau glukosa darah puasa $\geq 126 \mathrm{mg} / \mathrm{dl}$ sudah cukup untuk menegakkan diagnosis diabetes mellitus [16].

\section{Beras Merah}

Beras adalah bahan makanan pokok sebagian besar penduduk Indonesia. Saat dipanen, beras masih tertutup kulit sekam (epicarp). Beras juga dibungkus oleh kulit bagian dalam atau kulit ari (aleuron dan pericarp). Bulir padi yang dipanen selanjutnya melalui tahap pengeringan dan perontokan, pemecahan kulit dan penggilingan (http://www.tempointeraktif.com). secara umum masyarakat menggolongkan beras menjadi tiga, yaitu beras putih, beras ketan dan beras merah. Selama ini masyarakat hanya biasa mengonsumsi beras putih untuk kebutuhan sehari-hari, meskipun juga mengenal adanya beras merah. Beras merah belum terbiasa dikonsumsi layaknya beras putih. Beras merah umumnya hanya biasa dikonsumsi atau dipasarkan sebagai produk olahan untuk makanan bayi lanjutan dan konsumsi obat-obatan. Padahal padi beras merah (Oryza sativa L.) meupakan bahan pangan pokok yang bernilai kesehatan tinggi [17].

Beras merah atau brown rice adalah beras yang tidak digiling atau setengah digiling, jadi bisa dikatakan whole grain atau berbutir utuh. Beras merah mempunyai rasa sedikit seperti kacang dan lebih kenyal daripada beras putih [18]. beras merah umumnya diolah dengan ditumbuk atau dipecah kulitnya. Hal ini membuat kulit arinya yang berwarna merah masih utuh. Pada kulit arinya inilah terdapat kandungan protein, vitamin, mineral dan serat yang sangat penting bagi tubuh [19]. 
Berikut ini akan diuraikan kandungan dan manfaat beras merah:

a) Rendah karbohidrat namun tinggi kalori

Kandungan karbohidrat dalam beras merah lebih rendah daripada beras putih (78,9 g:75,7

g), tetapi nilai energi yang dihasilkan beras merah justru di atas beras putih (349 kal:353

kal). Oleh karena itu nasi beras merah seringkali direkomendasi sebagai bahan makanan yang baik untuk menurunkan berat badan [20].

b) Kaya protein

Dibandingkan beras putih, kandungan protein beras merah menurut [21], lebih tinggi $(6,8$ $\mathrm{g}: 8,2 \mathrm{~g}$ ). Protein merupakan agen pengatur bagi proses tubuh karena semua enzim dan hormon merupakan protein yang berperan sebagai alat transport zat gizi dan oksigen ke seluruh tubuh.

c) Mengandung asam lemak esensial

Lemak yang terkandund dalam beras merah adalah lemak esensial yang baik untuk perkembangan otak, maka sangat dianjurkan untuk diberikan pada bayi (di atas 6 bulan) dan anak-anak [22]. Selain itu, kandungan minyak pada lapisan kulit dalam padi dapat membantu menurunkan kolesterol LDL [23].

d) Kaya serat

Kandungan serat yang tinggi dalam beras merah tak hanya mengenyangkan, tetapi juga dapat menurunkan kolesterol darah [24]. Peranan serat untuk diabetes mellitus menurut [25] adalah meningkatkan viskositas lumen dalam usus sehingga akan menurunkan efisiensi penyerapan karbohidrat dan respon insulin.

e) Tinggi vitamin B1 (tiamin)

Beras merah memiliki kandungan vitamin B1 lebih tinggi dibandingkan beras putih $(0,12$ mg:0,31 mg). Tiamin berfungsi sebagai koenzim berbagai reaksi metabolisme energi. Untuk dekarboksilasi oksidatif piruvat menjadi asetil koA dan memungkinkan masuknya substrat yang dapat dioksidasi ke dalam siklus Krebs guna pembentukan energi. Kekurangan tiamin bisa mengganggu sistem saraf dan jantung, dalam keadaan berat dinamakan beri-beri

f) Selenium

Kandungan selenium dalam beras merah adalah $39 \mu \mathrm{m} / 100$ g. Selenium merupakan elemen kelumit (trace element) yang merupakan bahan esensial dari enzim glutation peroksidase. Enzim ini berperan sebagai katalisator dalam pemecahan peroksida menjadi ikatan yang tidak bersifat toksik peroksida dapat berubah menjadi radikal bebas yang mampu mengoksidasi asam lemak tidak jenuh dalam membran sel hingga merusak 
membran tersebut, menyebabkan kanker, dan penyakit degeneratif lainnya. Karena kemampuannya itulah banyak pakar mengatakan bahan ini mempunyai potensi untuk mencegah penyakit kanker dan penyakit degeneratif lain.

g) Fosfor

Kandungan fosfor dalam beras merah adalah $243 \mathrm{mg} / 100 \mathrm{~g}$. Melalui fosforilasi, fosfor mengaktifkan berbagai enzim dan vitamin B dalam pengalihan energi pada metabolisme karbohidrat, protein, dan lemak.

h) Antosianin

Antosianin merupakan pigmen merah yang terkandung pada perikarp dan tegmen (lapisan kulit) beras. Antosianin adalah senyawa fenolik yang masuk kelompok flavonoid dan berfungsi sbagai antioksidan. Peran antioksidan bagi kesehatan manusia untuk mencegah penyakit hati (hepatitis), kanker usus, stroke, diabetes, sangat esensial bagi fungsi otak dan mengurangi pengaruh penurunan fungsi otak.

\section{METODOLOGI PENELITIAN}

Penelitian ini bersifat analitik eksperimentalDesain penelitian yang digunakan dalam penelitian ini adalah quasy - experiment, rancangan ini berupaya untuk mengungkapkan hubungan sebab akibat dengan cara melibatkan kelompok kontrol disamping kelompok experimental. Tapi pemilihan kedua kelompok ini tidak menggunakan tekhnik acak [26]. dalam penelitian ini melalui observasi pada responden yang diteliti. Responden diobservasi tinggi dan berat badan untuk mengetahui kebutuhan kalori. Setelah itu sampel diambil darahnya untuk mengetahui kadar gula darah sebelum intervensi. Setelah mengetahui kadar gula darah masing-masing sampel, kemudian kelompok eksperimen diberi diet beras merah selama 1 minggu dengan frekuensi $3 \mathrm{X}$ sehari dengan porsi yang disesuaikan dengan kebutuhan kalorinya. Sedangkan kelompok kontrol tidak mendapat perlakuan diet beras merah. Setelah 1 minggu semua sampel kembali diukur kadar gula darahnya. Data yang diperoleh kemudian dimasukkan pada lembar observasi.

\section{Daftar Menu Sampel dalam Sehari}

Makan pagi (pkl 06.30) 


\begin{tabular}{|l|l|}
\hline Nasi & \multicolumn{1}{|l|}{ Jumlah } \\
Daging/Ikan Laut & sesuai \\
Tempe/Tahu & kebutuhan \\
Sayur & kalori \\
Minyak & \\
\hline \multicolumn{2}{|l|}{ Selingan (pkl 09.30): pisang 1 buah } \\
\hline \multicolumn{2}{|l|}{ Makan siang (pkl 12.30) } \\
\hline Nasi & \\
Daging/Ikan Laut & \\
Tempe/Tahu & \\
Sayur & \\
Minyak & \\
\hline Selingan (pkl 15.30): pisang dan kentang \\
@ 1 buah & \\
\hline Makan malam (pkl 18.30) & \\
\hline Nasi & \\
Daging/Ikan Laut & \\
Tempe/Tahu & \\
Sayur & \\
Minyak & \\
\hline Selingan (pkl 21.30): pisang dan kentang \\
@1 buah \\
\hline
\end{tabular}

\section{Alat dan Bahan Penelitian}

Populasi dalam penelitian ini adalah pasien DM di Puskesmas Pademawu, sejumlah 76 orang.Cara pengambilan sampel dalam penelitian ini adalah simple random sampling, pemilihan sample dengan cara ini merupakan jenis probabilitas yang paling sederhana. Untuk mencapai sampling ini, setiap elemen di seleksi secara acak. Instrument yang digunakan dalam penelitian ini berupa observasi secara langsung dengan mengukur kadar gula darah pada pasien DM di laboratorium Puskesmas Pademawu. Instrument yang digunakan untuk intervensi (perlakuan) dalam penelitian ini antara lain:

1. GlucoDr untuk mengukur kadar gula darah acak2. Weight Scale3. Untuk mengukur tinggi badan

\section{HASIL}

Berdasarkan hasil penelitian menunjukan bahwa pemberian diet beras merah efektif untuk menurunkan kadar gula darah pasien diabetes mellitus di puskesmas pademawu. Dari hasil data yang telah di tabulasi, kemudian diolah dengan bantuan komputer SPSS 11,0 untuk uji T sampel berpasangan di dapatkan hasil sebagai berikut: kelompok perlakuan setelah di beri perlakuan diet beras merah selama satu minggu terjadi penurunan kadar gula darah. Hal 
ini terbukti dengan nilai tingkat kemaknaan $(\mathrm{t}=0,05)$ menunjukkan nilai signifikan lebih kecil yaitu 0,000 dan nilai t hitung lebih besar dari pada nilai t tabel $(1,895)$ yaitu 7,202. Sedangkan hasil pengolahan data kelompok kontrol menunjukkan nilai signifikan lebih besar yaitu 0,188 dengan nilai thitung lebih kecil dari nilai t tabel yaitu $-1,457$. Hal ini berarti $\mathrm{H}_{0}$ diterima dan $\mathrm{H}_{1}$ ditolak. Setelah membandingkan hasil dari kelompok perlakuan dan kelompok kontrol menunjukkan bahwa diet beras merah efektif terhadap penurunan kadar gula darah pada penderita diabetes mellitus.

\section{PEMBAHASAN}

Proses penurunan kadar gula darah dengan pemberian diet beras merah dikarenakan kandungan serat yang tinggi pada beras merah. Serat tersebut selain mengenyangkan dan bagus untuk pencernaan juga dapat miningkatkan viskositas (suatu pernyataan tahanan dari suatu cairan untuk mengalir) lumen dalam usus sehingga akan menurunkan efisiensi penyerapan karbohidrat dan respon insulin.Dengan menurunnya respon insulin, kerja pankreas akan makin ringan sehingga dapat memperbaiki fungsi pankreas dalam menghasilkan insulin. Serat juga dapat menurunkan kadar lipit dalam serum sehingga dapat menekan kenaikan gula dalam darah. Karbohidrat yang ada dalam beras merah merupakan karbohidrat kompleks yang lambat di serap tubuh sehingga gula darah tidak meningkat dengan cepat. Beras merah juga mengandung mineral selenium dan pigmen antosianin (merah) yang berfungsi sebagai antioksidan dan penangkal berbagai macam penyakit degenaratif (penyakit yang mengiringi proses penuaan) termasuk diabetes mellitus.

Banyak faktor yang mempengaruhi kadar gula darah seseorang, salah satunya adalah faktor kegemukan, pada penelitian ini 37,5\% atau 6 orang adalah bertubuh gemuk, kelebihan berat badan mengakibatkan tubuh tidak peka lagi terhadap insulin (retensi insulin). Pasien diabetes di anjurkan untuk mempertahankan berat badan yang normal agar lebih mudah mengontrol kestabilan gula darahnya. 31,25\% reponden (5 orang) memiliki berat badan normal dan $31,25 \%$ bertubuh kurus.

\section{KESIMPULAN}

Berdasarkan hasil penelitian tentang Efektifitas Pemberian Diet Beras Merah dalam Menurunkan Kadar Gula Darah pada Penderita Diabetes Mellitus di Puskesmas Pademawu Pamekasandapat disimpulkanbahwa diet beras merah efektif menurunkan kadar gula darah pasien Diabetes Mellitus. 


\section{DAFTAR PUSTAKA}

1. _.(2006). Diabetes dan Penurunan Kualitas Hidup. Jakarta: www.medicastore.com/med/artikel.php?id=150\&iddtl=\&idktg=\&idobat=\&IUD=200 $\underline{81101094529125.164 .74 .82 .}$

2. _.(2007). Gizi Sehat dan Seimbang Mencegah Diabetes Mellitus. Jakarta: www.medicastore.com/med/artikel.php?id=215\&iddtl=\&idktg=\&idobat=\&IJID=200 $\underline{81013091 .}$

3. _.(2006).Informasi Diabetes Mellitus/Kencing Manis/Penyakit Gula DaeahPengertian, Definisi, Pencegahan, Perawatan, Petunjuk, dll. Jakarta: organisasi.org/informasi_diabetes_mellitus_kencing_manis_penyakit_gula_darah_pe ngertian_definisi_pencegahan_perawatan_petunjuk_dll.

4. _.(2007). Nutrisi Lebih Beras Merah. Jakarta: www.sportindo.com/page/116/Food_Nutrition/articles_tips/Nutrisi_Lebih_Beras_Mer ah.htm.

5. _.(2007). Pengaturan Makan Bagi Diabetesi. Jakarta: www.medicastore.com/med/artikel.php?id=201\&iddtl=\&idktg=\&idobat=\&IUD=200 $\underline{81101094526125.164 .74 .82}$.

6. _.(2008). Beras Merah. Jakarta: bpp.com/index.php?option=com_content\&task=viewq\&id=2988\&Itemid=47.

7. _.(2008). Faktor Lingkungan dan Gaya Hidup Berperan Besar Memicu Diabetes. Jakarta: www.pdpersi.co.id/?show=detailnews\&kode=914\&tbl=kesling.

8. _.(2008). Cemas Bikin Anda Rentan Diabetes. Jakarta: www.kesehatan.kompas.com/read/2008/07/28/12073317/cemas.bikin.anda.rentan.dia betes

9. _.(2009). Pasien Diabetes Harus Berhenti Merokok. Jakarta: www.kliniksehat.com/2009/03/22/pasien-diabetes-harus-berhenti-merokokkenapa/

10._(2009). Alcohol,american diabetes association. Amerika : http://www.diabetes.org/type-1-diabetes/alcohol.jsp

11. Akademi Keperawatan Pamekasan.(2014). Pedoman Penyusunan Karya Tulis Ilmiah.Edisi Baru. Pamekasan : Akademi Keperawatan Pamekasan.

12. Andrianto, Septian.(20 ). Diabetes. Jakarta: fkuii.org/tiki_download_wiki_attachment.php/attld=1030\&page=Septian\%20Andrian o.

13. Arixs.(2008). Sosialisasikan Beras Merah Harga Lebih Tinggi Baik untuk Kesehatan. Jakarta:

www.cybertokoh.com/mod.php? $\bmod =$ publisher\&op=viewarticle\&artid=4788.

14. Arikunto, S. (2005).Prosedur Penelitian Suatu Pendekatan Praktek. Jakarta: Rineka Cipta.

15. Arikunto, Suharsimi. (2010). Prosedur Penelitian. Edisi Revisi. Jakarta: Renika Cipta.

16. Astawan, Made \& Tutik wresdiyati.(2004). Diet Sehat dengan Makanan Berserat. Solo: Tiga Serangkai. 
17. Muchid, dkk.(2005). Jakarta:Pharmaceutical Care untuk Penyakit Diabetes Mellitus.125.160.76.194/bidang/yanmed/farmasi/Pharmaceutical/DM.pdf.

18. Nursalam.(2008). Konsep dan Penerapan Metodologi Penelitian Ilmu Keperawatan. Jakarta; Salemba Medika.

19. Dahlan Sopiyudun. (2012). Satistik Untuk Kedokteran Dan Kesehatan.Edisi Kelima..Jakarta: Salemba Medika

20. Arief.(2008). Habis Rokok Terbitlah Diabetes. Jakarta: www.drarief.com/?p=233

21. Arief.(2009).Diabetes,Stress dan Disfungsi Ereksi. Jakarta: www.serbaserbi.ariefew.com/renungan/diabetes-stress-dan-disfungsi-ereksi/

22. A. Azis Alimul.(2008). Metode Penelitian Keperawatan dan Teknik Analisis Data. Jakarta: Salemba Medika.

23. Istika, Auli dkk.(2007). Analisis Keperawatan Kasus Diabetes Mellitus. Jakarta: www.ziddu.com/downloadfile/1000063/AnalisisKeperawatanKasusDiabetesMelitus.p df.html.

24. Mansjoer, Arif dkk.(2005). Kapita Selekta Kedokteran. Jakarta: Media Aesculapius Fakultas Kedokteran Universitas Indonesia.

25. Master, Web.(2008). Gejala Tak Disadari Diabetes Mellitus. Batu raja: http://www.litbang.depkes.go.id/lokabaturaja/index.php?option=com_content\&task=v iew \&id=81\&Itemid $=1$

26. Pramita, Yuga.(2004). Beras Merah untuk Pria Loyo dan Mencegah Kanker. Jakarta: www2.kompas.com/kompas-cetak/0412/20/ilpeng/1445174.htm. 